potential marker for cerebral events during cardiopulmonary bypass. Ann Thorac Surg 1996;61:88-92.

24. Johnsson P, Lundqvist C, Lindgren A, Ferencz I, Alling C, Stahl E. Cerebral complications after cardiac surgery assessed by $\mathrm{S}$ 100 and NSE levels in blood. J Cardiothorac Vasc Anesth 1995;9: 694-9.

25. Schaarschmidt H, Prange HW, Reiber H. Neuron-specific enolase concentrations in blood as a prognostic parameter in cerebrovascular diseases. Stroke 1994;25:558-65.

26. Gao F, Harris DN, Sapsed-Byrne S, Sharp S. Neurone-specific enolase and Sangtec 100 assays during cardiac surgery. Part III. Does haemolysis affect their accuracy? Perfusion 1997;12:171-7.

27. Swets JA, Pickett RM, Whitehead SF, et al. Assessment of diagnostic technologies. Science 1979;205:753-9.

28. Hardemark HG, Ericsson N, Kotwica Z, et al. S-100 protein and neuron-specific enolase in CSF after experimental traumatic or focal ischemic brain damage. J Neurosurg 1989;71:727-31.

29. Schmidt R, Fazekas F, Offenbacher H, et al. Brain magnetic resonance imaging in coronary artery bypass grafts: a pre- and postoperative assessment. Neurology 1993;43:775-8.

\title{
Online-www.aats.org
}

Now you can get The Journal of Thoracic and Cardiovascular Surgery online. The Journal online brings you faster delivery time, easy searching of current and back issues, links to PubMed, AATS, WTSA, and other important sites, and more. Visit the Journal online today.

\section{Receive tables of contents by e-mail}

To receive the tables of contents by e-mail, sign up through our Web site at http://www.mosby.com/jtcvs. Choose E-mail Notification. Simply type your e-mail address in the box and click the Subscription button.

Alternatively, you may send an e-mail message to majordomo@mosby.com. Leave the subject line blank and type the following as the body of your message: subscribe jtcvs_toc.

You will receive an e-mail to confirm that you have been added to the mailing list. Note that table of contents e-mails will be sent out when a new issue is posted to the Web. 